\title{
AMERIČKI KUTAK ZADAR KAO KOMUNIKACIJSKA PLATFORMA ZA JEZIČNU I KULTURNU INTERAKCIJU
}

\author{
Cathy-Theresa Kolega \\ Zadarska privatna gimnazija \\ s pravom javnosti, Zadar, Hrvatska \\ cathy.kolega@yahoo.com
}

Primljeno: 25. 1. 2015.

\begin{abstract}
Ovaj rad donosi prikaz jednog oblika suradnje između Zadarske privatne gimnazije s pravom javnosti i Američkog kutka Zadar koji djeluje u sklopu Gradske knjižnice Zadar. Otkriva se što je to Američki kutak i na koji je način njegove programske sadržaje moguće inkorporirati u nastavu engleskog kao stranog jezika u srednjoj školi. Svrha je proširiti nastavne sadržaje autentičnim materijalima i pružiti učenicima mogućnost sudjelovanja u komunikaciji 'licem u lice's izvornim govornicima s američkog govornog područja te učiniti nastavu što zanimljivijom izlaskom iz okvira strogo didaktičke sredine. U radu se navodi nekoliko primjera iz prakse i određuju dobrobiti koje mogu proizaći iz ovakvih programa povezujući ih sodgojno-obrazovnim ishodima predmetnog kurikuluma za engleski kao strani jezik i to s aspekta jezične, komunikacijske i međukulturalne kompetencije.
\end{abstract}

Ključne riječi: Američki kutak, komunikacija 'licem u lice', izvorni govornici, jezična kompetencija, međukulturalna kompetencija

\section{Uvod}

U doba kada se promovira jezična izvrsnost i tečno vladanje stranim jezicima, biti nastavnik engleskog jezika kao stranog jezika unutar postojećeg formalnog obrazovnog sustava znači imati veliku odgovornost. Engleski je u pravilu prvi strani jezik koji se uči i jedan je od tri obvezna predmeta na Državnoj maturi koja, osim što podrazumijeva završetak srednjoškolskog obrazovanja, ujedno otvara vrata za daljnje 
akademsko obrazovanje. Stoga je jasno koliko važnu ulogu ima nastava engleskog kao stranog jezika u obrazovanju, i općenito.

Engleski jezik već dulje vrijeme uživa status svjetskog jezika i predstavlja osnovno sredstvo komunikacije u mnogim segmentima života modernog pojedinca i društva. Štoviše, suvremeno globalno tržište rada smatra jezično-komunikacijske kompetencije prioritetnima i nerijetko nameće potrebu poznavanja barem dvaju stranih jezika. Prema odredbama Europske Unije, prihvaćenima i od strane Obrazovne politike Republike Hrvatske, komunikacija na stranim jezicima predstavlja jednu od osam temeljnih kompetencija za cjeloživotno obrazovanje. Ona se odnosi na »osposobljenost za razumijevanje, usmeno i pisano izražavanje i tumačenje koncepata, misli, osjećaja, stavova i činjenica na stranomu jeziku u nizu različitih kulturnih i društvenih situacija« (Nacionalni obrazovni kurikulum, 2011, 17).

Kao značajna sastavnica ove kompetencije navodi se razvijanje vještina međukulturnog razumijevanja. Razvijanje vještina za stjecanje međukulturalne kompetencije (eng. intercultural competence) neizostavan je dio nastave stranih jezika. Jedan od načina da se učenici što više približe kulturi nekog naroda, u ovom slučaju onih s engleskog govornog područja, je korištenje različitih autentičnih materijala u nastavi kao što su novinski članci, kratke priče, audio-vizualni zapisi i slični mediji na engleskom jeziku. Komunikacija na stranom jeziku s izvornim govornicima u svakodnevnim životnim situacijama također pruža mogućnost upoznavanja sa stranom kulturom, odnosno priliku za jezičnu i kulturnu interakciju.

Posredstvom Američkog kutka moguće je ostvariti takve kontakte u sklopu dodatnih izvannastavnih aktivnosti. Očekivani ishodi odnose se na osvještavanje svrsishodnosti učenja engleskog jezika koji postaje sredstvo i cilj, a s obzirom da korištenje jezika izvan učionice u pravilu izaziva pozitivnu reakciju kod učenika može se očekivati i veća motivacija za učenje kao jedan od ključnih faktora za postizanje uspješnih rezultata.

\section{Što je Američki kutak?}

Američki kutak je kulturno-informacijski centar koji svojim korisnicima osigurava informacije i literaturu te organizira programe vezane uz američku kulturu, s osobitim naglaskom na engleski jezik i književ- 
nost, glazbu, povijest, obrazovanje, ekologiju, kao i aktualna zbivanja iz društvenog i političkog života. Riječ je o međunarodnom projektu koji je pokrenut 1998. godine, a trenutno je u svijetu aktivno više od 700 Američkih kutaka koji djeluju ili kao samostalna organizacija ili u sklopu ustanova kao što su kulturni centri i knjižnice. U Hrvatskoj ih ima četiri, a osnovani su u sklopu knjižnica u Osijeku, Rijeci, Zadru i Zagrebu (Belevski et al., 2013).

Američki kutak Zadar (American Corner Zadar) osnovan je u Gradskoj knjižnici u Zadru 13. lipnja 2005. godine temeljem potpisanog ugovora o suradnji (Memorandum of Understanding) između matične ustanove i Ureda za odnose s javnošću Veleposlanstva SAD-a u Zagrebu. Njegov se rad zasniva na principu multifunkcionalne public diplomacy platforme odnosno na međunarodnoj kulturno-socijalnoedukativnoj razmjeni informacija. Program Američkog kutka dobro se uklopio u rad knjižnice čiji je cilj svojim korisnicima približiti informacije, znanje i kulturu te ponuditi građu kojom se doprinosi nepristranom obavješćivanju građana, obrazovanju i bogaćenju kulturnog života svakog pojedinca u zajednici. Osobit naglasak stavlja se na edukaciju i obrazovanje te na poticanje suradnje s drugim institucijama i volonterima (Belevski, 2005).

Suradnja Američkog kutka Zadar i Zadarske privatne gimnazije s pravom javnosti traje od 2009. godine, a ostvaruje se u vidu provođenja različitih aktivnosti u sklopu nastave engleskog kao stranog jezika. U većini slučajeva riječ je o predavanjima ili radionicama koje vode izvorni govornici (sveučilišni profesori, znanstvenici, djelatnici Veleposlanstva) koji se posredstvom Veleposlanstva SAD-a zbog nekog posla zateknu u Republici Hrvatskoj. Aktivnosti su namijenjene učenicima i nastavnicima srednjih škola, ali i široj javnosti, odnosno svim zainteresiranim građanima. Dosadašnje iskustvo pokazuje da je za optimalne ishode koji mogu proizaći iz ovakvih programa poželjno da jezična kompetencija učenika-sudionika bude ona koja je na ljestvici kompetencija prema deskriptorima Zajedničkog europskog referentnog okvira za jezike (ZEROJ, 2005) označena s B1+. Sadržaji se prenose isključivo na engleskom jeziku, a teme koje se obrađuju usko su povezane sa školskim i predmetnim kurikulumom, prvenstveno engleskog kao stranog jezika, ali i nekih drugih školskih predmeta kao što su glazbena umjetnost, povijest, sociologija, etika ili biologija. Time se ostvaruje korelacija s predmetima kao jedna od poželjnih sastavnica kurikulu- 
ma. Istovremeno se otvara prostor za uvođenje međupredmetnih tema kao što je građanski odgoj i obrazovanje. Nadalje, riječ je o dobrom primjeru suradnje među institucijama, u ovom slučaju škole, Gradske knjižnice Zadar i Veleposlanstva SAD-a. Belevski (2005), koordinator i voditelj programa Američkog kutka Zadar, ističe mnoge prednosti koje ovakvi programi i načini suradnje mogu donijeti knjižnicama, svim sudionicima i zajednici uopće, kao što su promocija, ugled, donacije i, prvenstveno, razvoj međukulturne suradnje.

Važno je istaknuti da Američki kutak Zadar nudi i kolekciju knjiga, časopisa i ostalih publikacija te multimedijalne sadržaje, CD-e, DVD-e i slične materijale na engleskom jeziku koji mogu poslužiti kao dodatni nastavni materijali. Spomenuta građa je dio donacija Veleposlanstva SAD-a koje se potpisom gore navedenog ugovora o suradnji obvezuje osigurati svu opremu, građu i potporu za provođenje programa, a matična ustanova, u ovom slučaju Gradska knjižnica Zadar, obvezuje se osigurati prostor i aktivno sudjelovati u provođenju programa i nabavi građe te imenovati osobu (koordinatora, voditelja) za provođenje utvrđene suradnje.

Američki kutak mjesto je susreta američke i hrvatske kulture gdje se u okviru kulturne razmjene i promicanja razumijevanja dviju zemalja učenicima nudi prostor za razvijanje prijeko potrebne međukulturalne kompetencije i to u stvarnom kontekstu, izvan učionice, gdje je njena primjena nužna stvarnost.

\section{Razvijanje međukulturalne kompetencije}

U zadnjih nekoliko desetljeća dimenzija kulture i njeno poučavanje pobuđuju sve veće zanimanje brojnih stručnjaka koji se bave tom tematikom iz različitih aspekata. Rasprave i studije rezultirale su teorijama i metodološkim pravcima koji se, prema Byramu i Fengu (2004), mogu svrstati pod zajednički nazivnik poučavanje kulture za stjecanje međukulturalne kompetencije. Istovremeno je zabilježen porast broja različitih programa obuke čiji je cilj pripremiti polaznike za rad u višekulturnim sredinama ili u nekoj drugoj, stranoj kulturi. Byram i Feng (2004) govore i o potrebi za interakcijom između onih koji poučavaju kulturu unutar općeg obrazovanja i onih koji rade na razvijanju međukulturalnosti u poslovnom svijetu.

Aspekt kulture koji je neposredno vezan za jezik i njegovu uporabu smatra se neizostavnim dijelom nastave stranih jezika. 
»U učenju jezika kultura nije nebitna peta vještina, pridružena poučavanju govora, slušanja, čitanja i pisanja. Ona je uvijek u pozadini, spremna da neugodno iznenadi dobre učenike kada to najmanje očekuju, pokazujući ograničenja njihove teško stečene komunikativne kompetencije dovodeći u pitanje njihovu sposobnost da shvate svijet oko sebe.« (Kramsch, 1996, 1, u: MajhutRaše, 2007, 36)

U uvjetima rastuće globalizacije koju karakteriziraju česti kontakti i prožimanje različitih kultura, ciljevi nastave engleskog jezika trebali bi, prema Byramu (1997), biti usmjereni na pripremu učenika na međukulturalnu komunikaciju koja, kao dvodimenzionalan proces, uključuje jezičnu i međukulturalnu kompetenciju. Prema J. M. Benett (2011), međukulturalna kompetencija je skup kognitivnih, afektivnih i bihevioralnih vještina i obilježja koja čine učinkovitu i primjerenu komunikaciju u različitim kulturnim kontekstima. Kognitivne vještine i obilježja uključuju: kulturnu samosvijest, poznavanje opće kulture, poznavanje različitih kultura i analizu interakcije. Afektivne vještine i obilježja uključuju: znatiželju, kognitivnu fleksibilnost, motivaciju i otvorenost, dok se bihevioralne odnose na komunikativnost, sposobnost slušanja i rješavanja problema, suosjećanje i sposobnost prikupljanja informacija (Benett, 2011, u: Dragaš, 2013).

U Nacionalnom okvirnom kurikulumu za predškolski odgoj i obrazovanje te opće obvezno i srednjoškolsko obrazovanje (NOK, 2011), čije je temeljno obilježje prelazak na kompetencijski sustav i učenička postignuća (ishode učenja), jasno su naznačeni ishodi koji se odnose na međukulturalne kompetencije učenika u okviru nastave stranih jezika. U tom se dokumentu međukulturno djelovanje navodi kao peta kategorija kod stranih jezika koji spadaju pod jezično-komunikacijsko područje. Očekivana postignuća dijele se u tri kategorije: pripremanje za primjereno međukulturno djelovanje, primjenjivanje strategija za primjereno međukulturno djelovanje i primjenjivanje znanja, vještina i stavova radi uspješne međukulturalne komunikacije. Ukazuje se i na ishode u okviru četiriju jezičnih vještina - slušanja, govorenja, čitanja i pisanja - radi upoznavanja i poštivanja vlastite kulture i drugih kultura i to u sva četiri ciklusa. Ciklusi se odnose na pojedina razdoblja od početka do kraja obveznog dijela obrazovanja (od prvog razreda osnovne do završetka srednje škole).

Međutim, valja napomenuti da nije do kraja definirano kako teoriju sprovesti u djelo te da ne postoji jedinstven način razmišljanja kada je riječ o novom konceptu kulture, kao niti na koji način uvesti elemente 
kulture u nastavu. Još se složenijim čini kako osposobiti učenike da postignu zadovoljavajuću razinu međukulturalne kompetencije. U tradicionalnom pristupu koji se u literaturi spominje kao institucionalistički ili Landeskunde, nastava stranih jezika bila je usredotočena na prenošenje činjenica ili znanja o ciljnoj kulturi. S druge strane, novo, netradicionalno razumijevanje kulture iznjedrilo je kulturalistički usmjeren pristup ili nove kulturne studije usredotočene na značenja i vrijednosti. Veselica-Majhut i Raše (2007) pojašnjavaju različitosti u pristupu na primjeru odabira tema i tekstova i njihove primjene u nastavi. U tradicionalnom pristupu obrađivale su se teme kao što su monarhija ili sustav zdravstvene skrbi, dok se u modernom pristupu kod poučavanja kulture javljaju teme kao što su obrasci dokolice, potrošačkih navika ili produkcija i recepcija tekstova pop-kulture. Različito je i, primjerice, shvaćanje tekstova koji više nisu samo izvori informacija o ciljnoj kulturi koje učenik treba usvojiti nego služe kao polazišna točka za raspravu i daljnje istraživanje. Na višoj razini obrazovanja govori se o poučavanju kulture u okviru zasebnih kolegija gdje se kao cilj postavlja postizanje "poštovanja vrijednog akademskog oblika razumijevanja kulture« (Veselica-Majhut i Raše, 2007, 270).

Može se zaključiti da uvođenje međukulturalne dimenzije u nastavu engleskog kao stranog jezika nije novost niti da je za to nužno primijeniti neku posve novu revolucionarnu metodu, ali bi se nastavni sadržaji svakako više trebali prilagoditi suvremenim potrebama pojedinca od kojeg se očekuje da osim jezične kompetencije postigne i zadovoljavajuću razinu međukulturalne kompetencije. U ovome radu predstavljamo jedan dodatan način usvajanja jezika i kulture koji može pružiti dobru osnovu za stjecanje spomenute međukulturalne kompetencije u izravnom kontaktu s izvornim govornicima.

\section{Razvijanje jezično-komunikacijskih kompetencija}

S pojavom komunikacijskog pristupa 70-ih godina prošlog stoljeća došlo je do razvitka novih metoda poučavanja stranog jezika te se promijenila uloga nastavnika i učenika od kojih se očekuje aktivno sudjelovanje u nastavi. Dugo se mislilo, kao npr. Vrhovec (2001), da se u didaktičkoj sredini može oponašati komunikacija iz prirodne sredine. Međutim, analize su pokazale da se komunikacija u prirodnoj i didaktičkoj sredini razlikuju. Razred je umjetno stvorena komunikacijska 
sredina u kojoj se nastoje stvoriti optimalni uvjeti i pozitivno, opušteno ozračje kako bi se potaknulo učenike na komunikaciju na stranom jeziku. Tijekom nastavnog procesa na nastavi stranih jezika odvija se komunikacija između nastavnika i učenika te između učenika i učenika. Upravo Vrhovec (2001) ne propušta tvrditi kako se jezik uči putem komunikacije te da je u većoj mjeri potrebno poticati komunikaciju na relaciji učenik-učenik odnosno horizontalnu interakciju koja se postiže radom u paru ili radom u skupinama jer se na taj način učenicima pruža veća mogućnost za razvijanje komunikacijske kompetencije. Interakcija između nastavnika i učenika, odnosno vertikalna interakcija, trebala bi, prema istoj autorici, biti manje zastupljena u nastavi stranog jezika od horizontalne, s iznimkom učenja stranog jezika u ranijoj dobi gdje je nastavnik taj koji vodi, kontrolira i često prekida komunikaciju. Bošnjak Terzić (2012) smatra da u srednjoj školi, nakon što su učenici engleski jezik učili osam godina, komunikaciju na nastavi treba što više približiti prirodnoj komunikaciji. Uloga nastavnika u srednjoj školi znatno je drugačija od uloge nastavnika u osnovnoj školi te bi on trebao dopustiti učeniku da svojim jezičnim znanjem pokuša postići komunikacijski cilj, primjerice izrazi svoje mišljenje bez prekidanja, a komentare koje se odnose na jezične pogreške trebalo bi dati na kraju vježbe (razgovora) kako bi učenik znao na što treba obratiti pozornost u budućem govoru (Bošnjak Terzić, 2012).

Sudjelovanje učenika u programima Američkog kutka Zadar predstavlja primjer primjene nekih od navedenih načela u praksi. Budući da se u većini slučajeva oni realiziraju u Gradskoj knjižnici Zadar, nastoji se učiniti odmak od uobičajene didaktičke sredine, odnosno razreda, a umjetno stvoreno komunikacijsko ozračje u razredu zamijeniti prirodnom komunikacijom. Naime, predavanja izvornih govornika na engleskom jeziku predstavljaju jedan vid interaktivne komunikacije između predavača i učenika ili učenika i učenika. Budući da su predavači iz SAD-a, učenici imaju priliku biti u doticaju s autentičnim govornim jezikom i ljudima kojima je engleski u pravilu materinski jezik. Treba napomenuti da su odobreni udžbenici koji se koriste u nastavi engleskog kao stranog jezika u pravilu britanske edicije u kojima su učenici uglavnom izloženi standardnom britanskom engleskom jeziku. Općenito, izloženost stranom jeziku u kontaktu s izvornim govornicima jedan je od korisnih putova do usvajanja jezičnih elemenata. 
»Komunikacija s izvornim govornicima prilika je za svakoga kojemu taj jezik nije materinski da nauči nešto od sugovornika te da u svojem iskazu uporabi jezične elemente koje mu je pružio izvorni govornik svojim iskazom. Stoga bi svaki govornik u kontaktu sa strancem mogao graditi svoj govor s pomoću elemenata jezika cilja tako da ih pokuša uvrstiti u vlastiti jezični sustav.« (Vrhovec, 2001, 76)

Osim autentičnog jezičnog inputa, učenici imaju priliku razvijati i vještinu slušanja. Iako razumijevanje govora na stranom jeziku nije uvijek lagan zadatak i to posebno kada govore izvorni govornici, govornici se prilagođavaju ciljnoj publici. Očekivani ishodi su: učenici će izgraditi pozitivan odnos prema aktivnom slušanju na stranomu jeziku i steći samopouzdanje pri slušanju. Osim toga, za razliku od nedostatka neverbalnog i izvanjezičnog konteksta kada se u nastavi tekst sluša preko primjerice CD-a, ovdje učenici sudjeluju u neposrednoj komunikaciji koja uključuje elemente kao što su mimika lica i gestikulacija te govor tijela koji su sastavni dio žive komunikacije. Nadalje, mogu se razumjeti i svladati posebnosti izgovora i intonacije jezika (američki nasuprot britanskog) i uočiti razlike između standardnoga govora i tekstova izgovorenih u jezičnim registrima s obzirom da je riječ o prirodnom jezičnom kontekstu. Sve to može olakšati razumijevanje onoga što se čuje.

Predavači vrlo često koriste i različita audio-vizualna pomagala: CD-e, DVD-e i računalo, primjerice prezentacije u PowerPoint-u koje dopunjuju govorni tekst pa tako učenici ujedno razvijaju i ostale jezične vještine, kao što je vještina čitanja. Bitno je istaknuti da su ovdje autentični materijali neupitne kvalitete i prilagođeni publici. Ovo je važno jer bi kod odabira materijala bilo dobro izabrati one koji su zanimljivi i primjereni razini znanja učenika. Vještina pisanja može se vježbati tijekom predavanja ili radionice u vidu, primjerice, vođenja bilješki. Na predavanjima se primjenjuje metoda usmenog izlaganja, metoda objašnjavanja, metoda upita i traženja odgovora, metoda razgovora i metoda diskusije. Potičući učenike na razgovor i aktivno sudjelovanje u komunikaciji tijekom i/ili na kraju predavanja, razvija se i vještina govorenja. Budući da je konverzacija u pravilu opuštena (tipično američka), pojedinci vrlo rado postavljaju pitanja i ulaze u raspravu s predavačima, ali i s ostalim učenicima-sudionicima. Umjesto nastavnika koji postavlja pitanja kako bi se učenike potaknulo na razgovor, učenici postaju ti koji postavljaju pitanja jer žele nešto saznati. Vrijednost ovakvih susreta očituje se dakle i u motivaciji učenika da 
sudjeluju u komunikaciji na engleskom jeziku lišenoj pritiska straha od ocjenjivanja pa može utjecati i na eliminaciju straha od stranog jezika općenito. Učenici koji se aktivno uključuju u razgovor mogu prevladati nelagodu od govorenja na stranom jeziku i podići razinu samopouzdanja i samopoštovanja.

\section{Upoznavanje s američkom kulturom i razbijanje predrasuda i stereotipa}

U nastavi stranih jezika važno je razviti pozitivan odnos učenika prema zemlji, kulturi i narodu čiji se jezik uči. Općenito, stav prema navedenim elementima može u velikoj mjeri utjecati na motivaciju učenika za učenje nekog stranog jezika i biti ključan faktor pri odabiru stranog jezika, osobito ako je riječ o izbornom predmetu. Učenici ponekad imaju površan i negativan stav prema svemu što je strano. Kada je riječ o nečemu američkome, mogu se javiti stereotipna razmišljanja i predrasude: »Amerikanci jedu isključivo fast food «, »Svi Amerikanci nose bejzbol kapice« i slično. Programi Američkog kutka (predavanja, radionice, projekcije filmova, koncerti) mogu se iskoristiti za pobliže upoznavanje učenika sa stvarnim američkim načinom života: kulturom, povijesnim i društvenim zbivanjima, običajima, navikama itd. Također, temeljem iskustva iz prve ruke učenici mogu razviti kritičko mišljenje i izgraditi vlastiti stav prema različitim temama kojima se pridružuje pridjev američki. Bennett (1998) smatra da su stereotipi često povezani s tendencijom generaliziranja kulturnih obilježja te razlikuje pozitivne (kada prihvaćamo razlike) i negativne (kada odbijamo različitosti) kulturne stereotipe. Budući da su oni sastavni dio procesa kulturne interakcije tijekom kojega dolazi do uspoređivanja kulturnih obilježja, ponekad se mogu stvoriti određene prepreke u međukulturalnoj komunikaciji (Bennett, 1998, u: Sablić, 2014). Osim toga, predrasude mogu izrasti u nesnošljivost prema drugima koji se razlikuju po rasi, boji kože, nacionalnom podrijetlu, spolu, spolnoj orijentaciji, vjerskom ili političkom uvjerenju iz kojega se nadalje mogu pojaviti različiti vidovi diskriminacije kao što su rasizam ili ksenofobija.

Ovdje se navode neka iskustva iz prakse koja se mogu razmatrati kao način za ostvarivanje različitih odgojno-obrazovnih ishoda kao što su: razvijanje kritičkog mišljenja i objektivnog stava prema stra- 
noj, američkoj kulturi, rušenje stereotipa i predrasuda povezanih s poimanjem nečega što je američko, razvijanje kulturne svijesti, kulturne osjetljivosti i kompetencija koje se temelje na otvorenosti, poštovanju i prihvaćanju strane i vlastite kulture te za razvijanje cijelog niza općih kompetencija.

Tako su, primjerice, na predavanjima »Studirati u SAD-u« i »Pet koraka do studija u SAD-u « učenici, osim upoznavanja s programima koji se nude, dobili i širu sliku o obrazovnom sustavu i životu mladih ljudi u SAD-u i to na temelju iskustava dviju bivših studentica prestižnih američkih sveučilišta. Osnovni cilj bio je usporediti njihova stvarna iskustva s prikazom u tipičnim američkim filmovima koji se bave ovom tematikom. Raspravljalo se o stereotipima i predrasudama, vječitom rivalstvu između bogatih alfa studenata kao popularnih uzora i onih neuglednih koje svi preziru, a koji se nazivaju popularnim terminom nerds, o bulingu i sl. Ova tema također je poslužila za razvijanje vještine pisanja jer su učenici za domaći uradak trebali napisati esej raspravljačkog tipa iznoseći prednosti i nedostatke školovanja u inozemstvu. Ovoj pismenoj vježbi, koja je istovremeno dio nastavnog programa pripreme za polaganje Državne mature iz engleskog jezika na A razini, prethodilo je pisanje zabilješki tijekom predavanja. Cilj je pokušati napraviti što više dodatnih aktivnosti ovisno o temi nekog predavanja ili radionice. Učenicima se mogu zadati različite vježbe i zadatci ovisno o prethodno isplaniranim nastavnim ciljevima $\mathrm{i}$ ishodima koji mogu proizaći iz pojedinih tema koje se obrađuju.

Predavanje »Imigracija i obrazovanje « proširilo je temu obrazovnog sustava u SAD-u koji se u načelu, kao i ostali sustavi u modernom svijetu, trebaju temeljiti na uvažavanju različitosti i otvaranju širokog prostora za studij i rad bez obzira na spol, nacionalnu, vjersku ili rasnu pripadnost. Time se ukazalo na nužnost za međukulturnim djelovanjem. Ono predstavlja važno načelo prema kojemu se određuje stupanj demokracije i provođenja politike ravnopravnosti i poštivanja temeljnih ljudskih prava i slobode pojedinca. Inače, korijeni interkulturalizma kao kulturnog pluralizma sežu u 19. stoljeće. Interkulturalizam se pojavio kao opreka dotadašnjoj ideologiji lonca za taljenje (eng. melting pot) prema kojoj bi se različite druge etničke skupine na američkom tlu, radi integracije u američko društvo, trebale odreći svojega distinktivnog kulturnog podrijetla (Sablić, 2014). Na predavanju naslova »Raz- 
nolikost « iznijeti su podatci o tome koliko naroda različitog podrijetla, boje kože, rasa i vjerske pripadnosti trenutno živi u SAD-u. Nacija koja je stvorena od brojnih naroda koji su naselili prostore američkog kontinenta itekako shvaća važnost provođenja međukulturalnog odgoja i obrazovanja. Međutim, kritički se osvrnulo na zbivanja koja su tijekom povijesti dovela do negativnih pojavnosti koje se ne temelje na poštivanju i prihvaćanju različitosti, toleranciji i slobodi pojedinaca, već su oblici kršenja ljudskih prava i demokracije, kao što su razni oblici diskriminacije, segregacija i slično. Naglasak je stavljen na pravo svakog djeteta na školovanje bez obzira na njegovo podrijetlo ili pripadnost.

O rasizmu i diskriminaciji na rasnoj i spolnoj osnovi kroz povijest i danas raspravljalo se na predavanjima »Utjecaj Afroameričkih žena« i »Poznate američke žene« ističući njihov put stalne borbe za ljudska prava i emancipaciju žena. Kritičan stav iznesen je prema suvremenom američkom društvu u kojemu su žene još uvijek u neravnopravnom položaju u odnosu na muškarce. Zanimljivo je spomenuti da su učenici uočili pozitivne pomake na tom planu, usporedivši ropstvo kao negativan primjer iz američke prošlosti (ova tema obrađena je na predavanju »Abraham Lincoln«) i činjenicu da su aktualni predsjednik i prva dama Sjedinjenih Američkih Država Afroamerikanci.

Od glazbenih tema značajno je izdvojiti predavanje »Hip-Hop« koje je potvrdilo važnost glazbenih medija kao nositelja međukulturalne komunikacije. Kao glazbeni izričaj koji uz rap progovara o aktualnim problemima pojedinca i društva i to na kreativan način, učenici su pokazali ogromno zanimanje za sudjelovanjem u diskusiji na njima poznatu temu što spada u jedan od obrazovnih ishoda nastave engleskog kao stranog jezika. Navođenje hrvatskih primjera s osvrtom na tekstove može se promatrati kao jezično-kulturna interakcija između učenika i predavača kao predstavnika strane kulture. Time se mogu stvoriti uvjeti za ostvarivanje očekivanih ishoda nastave engleskog kao stranog jezika koji se odnose na međukulturno djelovanje i razvijanje međukulturalne kompetencije. To su: razvijanje svijesti o vlastitoj i drugoj kulturi, uspoređivanje vlastite kulture s drugom kulturom, iznošenje, uspoređivanje ili mijenjanje određenih stavova i uvjerenja. Rock ' $n$ ' Roll je tema u korelaciji sa sociologijom, a predstavljena je s nekoliko aspekata kao važan element američkog društva, odnosno glazbe kao neizostavnog dijela njihove pop-kulture. 


\section{Zaključak}

Nastava engleskog kao stranog jezika trebala bi biti usmjerena na one odgojno-obrazovne ishode koji odgovaraju potrebama suvremenog pojedinca i društva. U NOK-u, koji se u teoriji oslanja na ZEROJ kao temeljni dokument jezične politike EU, jasno je naznačeno da jezičnokomunikacijske kompetencije spadaju na sam vrh ljestvice važnosti, a njihovo stjecanje predstavlja preduvjet da se mladi ljudi po završetku svog obveznog dijela školovanja mogu uspješno uključiti u daljnji život. Globalizacija briše postojeće vidljive i nevidljive granice, a bolja komunikacija vodi većoj mobilnosti i neposrednijem uspostavljanju kontakata pa su ciljevi kojima teži usmena i pisana komunikacija na visokoj razini. Engleski jezik globalno je sredstvo komunikacije ili lingua franca pa je sve više onih kojima taj jezik nije materinski. Stoga se u današnjim uvjetima, osim izvrsne jezične kompetencije, traži i razvijena međukulturalna kompetencija. Čini se da je nastavu engleskog kao stranog jezika potrebno stalno proširivati sadržajima usmjerenima na stjecanje spomenutih kompetencija. Osim kultura naroda s isključivo engleskog govornog područja, u udžbenicima se sve više pojavljuju teme koje se odnose i na narode koji to nisu. Međutim, vrlo često su to generalizirani prikazi.

U nastojanju da se učenike koji uče engleski kao strani jezik približi stvarnom životu, jeziku i kulturi naroda kojima je on materinski moguće je posredstvom Američkog kutka Zadar, koji djeluje u sklopu Gradske knjižnice Zadar, organizirati predavanja, radionice i sl. Treba istaknuti da je ovo samo jedan vid suradnje škole s Američkim kutkom te da on djeluje kao komunikacijska platforma za širu javnost, odnosno sve one koji se na određen način zanimaju za elemente američke kulture, društva itd.

Posebnosti sudjelovanja u ovakvim programa mogu se opravdati činjenicom da učenici na ovaj način ostvaruju neposredan kontakt $\mathrm{s}$ izvornim govornicima u živoj komunikaciji na engleskom jeziku. Unatoč tome što je izloženost učenika engleskom jeziku danas kudikamo veća nego ranije zbog naprednih modernih tehnologija, osobito Interneta, kao i činjenice da su različiti izvori na engleskom jeziku dostupniji nego ranije, ovakve prilike gdje se ostvaruje komunikacija sa stvarnim ljudima-izvornim govornicima smatramo vrlo korisnima i poticajnima. Govorna interakcija i komuniciranje licem u lice može imati pozitivan učinak na učenje i proces usvajanja stranog jezika te se učenici mogu 
dodatno motivirati za rad, dok je izlazak iz stroge didaktičke sredine odnosno učionice, u pravilu pozitivno prihvaćen.

Dobrobiti koje mogu proizaći iz ovakvih aktivnosti su i te što one mogu poslužiti kao priprema za međukulturno djelovanje. Poslanje Američkog kutka je promoviranje međusobnog razumijevanja naroda, a to se poklapa s odgojno-obrazovnim ishodima predmetnog kurikuluma za engleski jezik kao što su: razvijati dobar odnos prema (stranom) jeziku i narodu, razvijanje tolerancije i uvažavanje različitosti, razvijanje kritičkog mišljenja, stvaranje objektivnog stava prema različitostima, rušenje predrasuda i stereotipa, usporedba vlastite kulture, načina života i tradicije sa stranom itd. Općenito se može doprinijeti i povećanju sposobnosti daljnjeg učenja jezika i otvorenosti prema novim kulturnim iskustvima, kao i razvoju vještina i umijeća za stjecanje potrebne razine međukulturalne kompetencije.

\section{Literatura}

Belevski, Milko (2005), »Američki kutak u Zadru«, Novosti, Hrvatsko knjižničarsko društvo, 30, str. 15-16. Dostupno na: file://C:/Users/admin/Downloads/ HKD_Novosti_30.pdf.

Belevski, Milko (2010), »Konferencija Američkih kutaka«, Novosti, Hrvatsko knjižničarsko društvo, 49. Dostupno na: http://www.hkdrustvo.hr/hkdnovosti/clanak/290.

Belevski, Milko et al. (2013), »Trenutak za američki kutak«, Novosti, Hrvatsko knjižničarsko društvo, 58, str. 34-39. Dostupno na: http://www.hkdrustvo. $\mathrm{hr} / \mathrm{hkdnovosti/clanak/628.}$

Bošnjak Terzić, Brankica (2012), »Udžbenički tekstovi kao poticaj za razvijanje komunikacijskih vještina«, Strani jezici, Zagreb: Odjel za strane jezike $\mathrm{Hr}$ vatskog filološkog društva u suradnji sa Školskom knjigom, 41(4), str. 367380.

Byram, Michael (1997), Teaching and Assessing Intercultural Communicatice Competence, Clevedon: Multilingual Matters Ltd.

Byram, Michael i Feng, Anwei (2004), »Culture and language Learning: Teaching, research and scholarship«, Language Teaching, 37, str. 149-168.

Dragaš, Marija (2013), »Interkulturalna komunikacija u poslovnom engleskom jeziku - pregled temeljnih pojmova«, Zbornik radova Međimurskog veleučilišta u Čakovcu, 4(1), str. 17-20.

How to Run an American Corner: A Guide for Embassy Partners (2010), U. S. Department of State, Bureau of International Information Programs, Office of Information Programs. 
Nacionalni okvirni kurikulum za predškolski odgoj i obrazovanje te opće obvezno i srednjoškolsko obrazovanje (2011), Zagreb: Ministarstvo znanosti, obrazovanja i športa RH.

Petrović, Elvira (1988), Teorija nastave stranih jezika, Zagreb: Školska knjiga.

Sablić, Marija (2014), Interkulturalizam u nastavi, Zagreb: Ljevak.

Veselica-Majhut, Snježana i Raše, Tea (2007), »Nekoliko bilježaka o poučavanju kulture na studiju engleskog jezika«, Strani jezici, Zagreb: Odjel za strane jezike Hrvatskog filološkog društva u suradnji sa Školskom knjigom, 36(3), str. 269-272.

Vrhovec, Yvonne (2001), Govorna komunikacija i interakcija na satu stranoga jezika, Zagreb: Ljevak.

Zajednički europski referentni okvir za jezike: učenje, poučavanje, vrednovanje (2005), Vijeće Europe, Zagreb: Školska knjiga.

\title{
AMERICAN CORNER ZADAR AS COMMUNICATION PLATFORM FOR LINGUISTIC AND CULTURAL INTERACTION
}

\author{
Cathy-Theresa Kolega
}

This paper presents a form of collaboration between Zadar Private High School and American Corner Zadar, which is an integral part of the Zadar Public Library. What is American Corner and how its programme can be incorporated into Teaching English as a foreign language (TEFL) is also elaborated. The aims are: to expand curriculum contents by using authentic materials, to provide students with a possibility to take part in direct face-to-face communication with American native speakers, and to make language learning more interesting by leaving a formal learning environment. Some practical examples are also included in the paper. The benefits of such programmes are specified according to the educational outcomes of the curriculum for English as a foreign language considering the linguistic, communicative and intercultural aspect of competences.

Key words: American Corner, face-to-face communication, native speakers, linguistic competence, intercultural competence 